\title{
Self-Government in One Hundred Years of Solitude: A Contributing Factor in Originating Dominant, Residual, and Emergent Perspectives
}

Golchin Amani

\author{
M.A. of English Literature, University of Kurdistan \\ Email: amani2015.g@gmail.com
}

\section{Zakarya Bezdoode}

Assistant Professor of English Literature, University of Kurdistan Email: zbezdodeh@gmail.com

\section{Doi:10.5901/mjss.2016.v7n4p}

\section{Abstract}

The present paper seeks to examine the way Gabriel García Márquez negotiates "Dominant, Residual and Emergent" perspectives in One Hundred Years of Solitude. Our main concern is to demonstrate to what extent the individuals' agency could be effective in regard to the formation of the dominant ideology which shares a lion part of the culture. Furthermore, the way concepts like culture, ideology, transformation, colors, books, music, and borders play role in cultural materialism will be thoroughly explored in this paper. The paper concludes that individuals are the most influential rule-definers. As an illustration, the individuals themselves help the transition from polygamy to monogamy in the family structures. In addition, the very fact that most of the emergent perspectives were at some times dominant and have been covered in cobweb-like layers and are now recalled in the form of novel things is manifested.

Keywords: Gabriel García Márquez, Raymond Williams, Cultural Materialism, Dominant, Residual, Emergent, Individual's SelfGovernment, Monogamy, Polygamy

\section{Introduction}

No longer can social action be seen as the result of some meta-social principles--such as Tradition, God, Reason, the Economy, or the State; society itself is the result of a set of systems of action involving actors who may have conflictual interests but who share certain cultural orientations. (2005, Amoore, p. 302)

One Hundred Years of Solitude is a 1967 novel by the Colombian author Gabriel García Márquez (1927-2014). It tells the multi-generational story of the Buendía family, the very first male figure of which, José Arcadio Buendía, finds the town of Macondo, "an allegory of Latin America as a whole" (Martin, 2012, p. 47). The village is first discovered by the gypsies who bring their discoveries there. The leading figure of these visitors is Melquidas. More visitors enter Macondo and some civil wars occur in the novel. Although the new comers show some points of prosperity, they lead to the decline of the village. The novel ends in the simultaneous death and birth of a child whose name is Rudrigo. He is the offspring of an illegitimate love affair between an aunt and a nephew. The infant is finally devoured by ants. The very ending of the lives of Buendia family had been primarily predicted by Melquidas, and now that Aureliano Babilonia, the nephew attempts to discover the mysteries in Melquidas's manuscripts, he perishes in a strong storm. Such an occurrence coincides with the discoveries of Melquidas's coded manuscripts in which he predicted that a child with a pig tail will be born, the last member will sweep away in a strong storm. Consequently, the child's mother dies of the bleeding after the childbirth. Marquez tells the story of a family which for a hundred years did their best to prevent having a child with pig's tail; however, their very efforts in preventing it were useless.

The present paper tends to study the way Gabriel García Márquez interrogates "Dominant, Residual and Emergent" perspectives (as defined by Reymond Williams) in One Hundred Years of Solitude. Our main attempt is to demonstrate to what extent the individuals' agency could be effective in regard to the formation of the dominant ideology which shares a lion part of the culture. In addition, the way concepts like culture, ideology, transformation, unsuccessful emerges, original balance and equilibrium, customer/service, colors, books, music, borders, and gift and gift giving play role in cultural materialism will be explored in this paper. 
In terms of what has already been offered, this paper seeks to answer the following questions through an analysis of One Hundred Years of Solitude:

- Is the individual's involvement in the inauguration of cultural changes effective?

- How do the individuals' ideologies help the conduction of social changes?

- How does each individual's originality affect the channel through which they act?

- Are all of the individuals' attempts to bring about changes successful?

- How do the brought about changes affect the familial issues like polygamy and monogamy?

Raymond Henry Williams (1921-1988) is a Welsh academic, novelist and critic. Culture is one of the widely discussed concepts in his cultural materialist approach. He defines culture "as a theory of relations between elements in a whole way of life" (Williams, 1958, p. VI). As a result, culture is not an isolated or fixed entity. Culture is closely associated with the three perspectives "residual," "emergent" and "dominant."

Dominant culture is the culture practiced at the present time. What cannot be expressed or verified in terms of the dominant culture are lived and practiced in the residual and what comes out of the dominant culture as new meanings and values, new practices and relationships are called emergent. (Sims, 1994, pp. 223-234)

The dominant culture which is the norm and takes the majority of institutions under its own control could be equated to hegemony. Williams introduces residual as an active and not a passive element, he notes that residual "has been effectively formed in the past, but it is still active in the cultural process, not only as an element of the past, but as an effective element of the present" (Williams, 1977, p. 122). Residual could be both supported to survive and neglected to vanish. Furthermore, Williams clarifies the difference between the residual and the archaic. He presents that, "Archaic is wholly recognized as an element of the past" (Williams, 1977, p. 122). Among the influential factors in the fluid transitions of the enumerated perspectives, one can name individuals as the "authentic" selves or the pioneers of social changes (Williams, 1961, p. 103).

Ochoa (2005) studies the role of macondismo as an ideology in inaugurating the canonic validity of Vallenato as a folk genre from the Colombian Caribbean. Ortega (2014) notes the poststructuralist tendencies in Garcia Marquez' novels and focuses exclusively on the sign-system, intradiscursivity, and representation. Booker (1993) scrutinizes García Márquez's Love in the Time of Cholera and argues that although the text invites its readers to read it as a love story, the reader has to be cautious about the seductiveness of narrative and should be warned against gullibility in the reading of texts or of the world. Miller (2014) proposes a meticulous investigation of the male characters' names in One Hundred Years of Solitude and concludes that although in Macondo everything is so recent that most of them have not been given a name yet, Garcia Marquez "has used the names in their traditional symbolic or allegorical as well as semantic interpretation" (p. 72-73).

Vega-González (2001) acknowledges the similarities between the novels of García Márquez and Morrison. She focuses on the use of memory and imagination. The scrutinized texts tell the stories of characters who search for their family history along their own identity amidst the dangers of capitalism and its excessive desire for progress and class ascendance. The break with narrative linearity, the reliance on the supernatural and the advocacy of hybridity are among the features that associate Morrison and García Márquez with magic realism.

Moraña (1990) criticizes the anachronistic plot of romantic love in Love in the Time of Cholera. Aizenberg (1992) addresses the problematic rediscovery of history in Gabriel García Márquez's One Hundred Years of Solitude and Yambo Ouologuem's Bound to Violence. Finally, the author concludes that the novels' violent narrative strategies reflect them as the products of a ruptured history scarred by imperialization. Ruckel (2006) suggests that both Faulkner and García Márquez use the olfactory as the human beings' main sensory system in their novels. That is to say, both of them use the sense of smell in order to get at truth.

Comparing Beloved and One Hundred Years of Solitude, Ericson (2009) states that "Both novels make their readers imaginatively engage with their spectral metaphorics to emphasize their readers' agency and responsibility within the unfinished business of historical reality" (p. 224). Browitt (2007) refers to Vargas Llosa's concept of total novel in which Llosa introduces the concept of total novel and names One Hundred Years of Solitude as one of its manifestations and asserts that One Hundred Years of Solitude is a:

'total' because of its utopian design as a supplantor of God: it describes a total reality and confronts that reality with an image which is its expression and its negation... It is also a total novel because of its material, in that it describes a closed world, from birth to death. (pp. 17-21) 


\title{
2. Discussion and Analysis
}

The gypsy proclaimed that "Things have a life of their own," and "It's simply a matter of waking up their souls" (Marquez, p. 1). What one can comprehend from Marquez is that what is called emergent by Williams is not an invented perspective, but a discovered one in that such a perspective had existed before its investigation and by being brought to the center of focus, it becomes an emergent aspect of life. "Nothing happens or exists in the social world unless it is framed by human performative activity" (Harré, 2002, Abstract). It is our call that gives voice to something and awakens and rescues them from becoming obsolete. Therefore, the gypsies that used to come to Macondo were the originator of new inventions; when they did not appear any longer, their emergent ways of doing things disappeared and failed to transfer. Comparing idealism and materialism, Williams (1958) claims that:

The importance of each position ... is that it leads ... to intensive study of the relations between "cultural" activities and other forms of social life ... The sociology of culture, as it entered the second half of the twentieth century, was broadly compounded of work done from these two positions. (p. 8)

\section{Williams continues that:}

\begin{abstract}
a new kind of convergence is becoming evident, it differs in its insistence that "cultural practice" and "cultural production" are not simply derived from an otherwise constituted social order but are themselves major elements in its constitution, it sees culture as the signifying system through which necessarily a social order is communicated, reproduced, experienced and explored. (ibid, pp. 12-13)
\end{abstract}

If we take "cultural production" both as an emergent element and a symbol of individual actions, we can conclude that the materials of forming changes are achieved by the very individuals themselves. Elites are those who bring about emergent perspectives, transitions, and changes. Leavis's study (as cited in Milner, 2002) depicts that "For Eliot, the cultural elite will tend to attach itself to the dominant class" (p. 33). "Elites bring state apparatuses and agencies and institutions of civil society" (Sklair, 1998, p. 13). Subsequently, elites as the prototype of influential subjectivities are the generators of remarkable social changes.

Sheumaker \& Wajda (2008) refer to "book" as "an ancient cultural entity whose material form has long embodied its social and cultural significance"; in addition,

Printed books have long been a powerful agent of two often intertwined forces. They have helped both in clarifying diversity within societies, and their material forms often help to articulate the distinctions among cultural communities, because they are markers of social class, and signal wealth, education, family lineage, and "taste." and the books are often credited with enabling a broader, more democratic access to a common, uniform fund of information and ideas. ( $p$. 70)

It is completely manifested in One Hundred Years of Solitude in that this is by the help of such books as the body of standardized knowledge that Auerliano becomes that knowledgeable to decode the parchments and manuscripts. Sheumaker \& Wajda (2008) refer to the concept of childhood and assert that "Adults have shaped and continue to shape, the environments and experiences of childhood through the dominant values they establish and maintain;" then she adds that the material culture of childhood has often mirrored aspects of children and their curiosity about the longer world makes the familiar a place of wonder and amusement" (p. 83). In the novel we observe that Auerliano is deprived of experiencing childhood in an open environment that even when he is given the opportunity in a later stage, he does not show any tendency to use it and sticks to the symbolic tools, like the books that connect him in a way to the outer world.

Roberts \& Vander Linden (2011) believe that "metal is simply one material that is reshaped according to the expectations and desires of the communities involved" (p. 12). The significance of metal is presented by Marquez when the gold fishes are exchanged with gold coins then melted to make fish again; in fact it is the "reshaping" of the original material. This particular family need such an emblem, a material object here (a gold metal), to be recognized with. It indicates that the very original material of an object or ideology is taking energy from the previously existed sources. Although such changes may be in a somehow different form, they are the same in nature; we can refer to it as an essence which emanates from fixed desires in human nature. In fact they are materializing their own ideologies through specific objects. So the creators of ideologies are the same human beings who later reshape it based on their own desires

Woodward (2007) refers to Feathersone's discussion of "the anesthetization of everyday life" by which he means in a society where the commodity sign dominates, each person must be a symbolic specialist. This discussion is applicable 
to consumer culture in two ways. The first is related to our research which is "where life is conceptualized as a project of styles, where originality, taste and aesthetic competence are measures of success and superiority" (pp. 23-24, my italics). It is claimed that "the goal of most conservative and restoration work is to return an object to its original condition" (Sheumaker \& Wajda, 2008, p. 290). All through the novel, women are trying to bring back the house to its original conditions. An instance for this returning to originality is observed in the birds brought by Fernanda which flew back to their original place

Sheumaker \& Wajda (2008) elaborate on the role of commodity and note that commodity complicates the boundaries between art, folk, and mass and of the role of the authentic in scholarly discussions of culture and experience. They add that:

The commodity as a category of analysis focuses inquiry on the complexity of material objects: how they are produced, by whom, out of what materials, and within which culture they circulate to lend meaning to the lives of those who consume them. ( p. 115)

Once the gypsies were dominant; however, by the death of Melquidas they became residual and were ignored. Here we have the revival of residual in that Aureliano Segundo opens the room of Melqudas and starts reading his manuscripts. He tends to discover the manuscripts; therefore, he confines himself with those writings and is astonished by them. While being entertained by the books, he is not that concerned with matters such as love affair. Aureliano Segundo was deep in the reading of a book. Although it had no cover and the title did not appear anywhere, the boy enjoyed the story of a woman who sat at a table and ate nothing but kernels of rice, which she picked up with a pin, and the story of the fisherman who borrowed a weight for his net from a neighbor and when he gave him a fish in payment later it had a diamond in its stomach, and the one about the lamp that fulfilled wishes and stories about the flying carpets. He was surprised and asked Úrsula if all that was true! She replied "yes, it was" and added that many years ago the gypsies had brought magic lamps and flying mats to Macondo. "What's happening," she sighed, "is that the world is slowly coming to an end and those things don't come here anymore" (Marquez, p. 94).

This historical era as foreseen by Úrsula is put to an end and ends in the awakening of what was once observed by the gypsies; possibly, in the next generation, all of the events that happened to Beuendia family could be repeated for the next generation. The new inventions like magnets, cameras, magnifying glass, are at first emergent, but after a while when a large number of people acquire them, they become dominant and later on by the emergence of new discoveries and inventions they become residual. Melquidas asserts that "science has eliminated distance; in a short time, man will be able to see what is happening in any place in the world without leaving his own house" (Marquez, p. 8). He indirectly suggests that such new inventions will become dominant to the extent that everybody will be able to feel their advantages. The first person who supports and provides encouragement for the advertisements of these gypsies is Jose Arcadio Beuendia. He epitomizes those groups that for the first time welcome the emerging concepts; therefore, by being their customer, he becomes both a buyer of new technology and of new ideology. In fact, Jose Arcadio Buendia welcomes the idea of rejecting international border.

Commodity is defined as something that can be exchanged. Objects enter into and out of the spheres of commoditization so that an object which is now a commodity might not always remain a commodity due to its incorporation to private or virtual worlds of individuals, families, and cultures. It demonstrates that whenever a new idea is created, it needs somebody to welcome it, to be the customer of services provided by such channels and on the other hand, if we look at the discussion from an economical view point, it shows that the gypsies are economically dependent on non-gypsies. Items are advertised to become dominant, e.g. Woodward (2007) in his elaboration on the consumption in the $19^{\text {th }}$ century refers to Mc Cracken and asserts that the institutions have changed their way in introducing their goods, the place in which people consumed and the styles of life to which this new consumption was devoted. (p. 116). Therefore, they are calling people to become their customers in a new way.

Simmel (1957) provides a detailed discussion about fashion by asserting that fashion is at first exercised by a few number of people then it is practiced by almost all and after a while that it spreads universally, it gradually goes to its doom (p. 547). As a result, what happens to fashion is very similar to the three changes that a phenomenon goes through in that it has to be first emergent then dominant then it may become residual. Sometimes the emergent perspectives are not successful; for instance, Fernanda in One Hundred Years of Solitude brings about some civilized etiquettes and mannerism to her husband's family life; these etiquettes are emergent ones; for example, it is suggested that the purpose of etiquette as a set of rules that govern social behavior is to regulate social behavior. Besides, it offers the means by which people express their feelings. It facilitates communication between individuals and displays one's place in the social order (Sheumaker \& Wajda, 2008, pp. 178). Although Fernanda attempts to actualize her culture's etiquettes, she 
does not succeed in holding them for a long time in order to make them dominant.

The emergent etiquettes introduced by Fernanda do not have the potential to become dominant in that the next generation and the new immigrants do not respect such manners. The fact that such etiquettes do not have the capacity to become dominant is that they are defined prescriptively rather than descriptively, and the occasions on which they might be appropriate are not well-defined. In the earlier paragraphs, states in which emergent perspectives lose their popularity and are replaced by new emergent perspectives were introduced. An explicit example to modify this case is manifested in the following quotation

José Arcadio Buendia, who had still not been consoled for the failure of big magnets, conceived the idea of using that invention as a weapon of war. Again Melquiades tried to dissuade him, but he finally accepted the two magnetized ingots and three colonial coins in exchange for the magnifying glass. (Marquez, p. 8)

Once he traded his mule and a pair of goats for the two magnetized ingots, and now he trades the two magnetized ingots for the magnifying glass. Then he expands his interest towards more complicated instruments so that he "abandoned his domestic obligations" (Marquez, 9). It shows some family changes that the more we move towards the end of the novel, the clearer such transitions become. According to the above quotation:

By then Melquíades had aged with surprising rapidity. On his first trips he seemed to be the same age as José Arcadio Buendía. But while the latter had preserved his extraordinary strength, which permitted him to pull down a horse by grabbing its ears, the gypsy seemed to have been worn dowse by some tenacious illness. It was, in reality, the result of multiple and rare diseases contracted on his innumerable trips around the world. (Marquez, p. 10)

We find that the more knowledge and experience we get from the world, the more we suffer and perish. Consequently, the more emergent concepts we experience, the more fragile and unpredictable our culture becomes. That is due to the fact that constant changes deprive us of acquiring a fixed and original basis and make us move like a pendulum between various perspectives. Most of the time when we have a feeling of being endangered, we avoid experiencing any problematic issue, whereas the very curious nature of human being paves the way for more experiences. In this way the possibility of the occurrence of emergent perspective increases. "When the gypsies came back, Úrsula had turned the whole population of the village against them. But curiosity was greater than fear" (Marquez, p. 11). It is the sense of curiosity that leads to the emergence of emergent perspectives. The discussion over these three perspectives is not restricted to Melquidas's group of gypsies. It is claimed that:

In his youth, José Arcadio Buendia and his men, with wives and children, animals and all kinds of domestic implements, had crossed the mountains in search of an outlet to the sea, and after twenty-six months they gave up the expedition and founded Macondo, so they would not have to go back. (Marquez, p. 12)

Jose Arcadio Beuendia's family once came to Macondo and settled there, at first they were emergent (new) comers; however, they are the dominant family there now. In another section of the novel the author tells that "where no one had died" (Marquez, p. 11). Consequently, at first it has been a new place, found by Beuendia family without any previous residents. Probably, they themselves were once gypsies like Mequidas, and had made themselves dominant by making the place their permanent settling place. "But that time Úrsula had anticipated his feverish designs. With the secret and implacable labor of a small ant she predisposed the women of the village against the flightiness of their husbands, who were already preparing for the move" (Marquez, p. 13). For the first time we observe that Úrsula Iguran leads her husband's decision to failure, not only her, but also all of the women in the village stop their husbands from following what Jose Arcadia Beuendia had already told them to do

The gypsies that arrived there were from the same group led by Melquidas; however, they had some changes in their approach and language, the point that drew attention towards them was new inventions. It demonstrates that the concepts that an object carries with itself is much more important than their carriers. People are the customers of new ideologies, and technologies. The residents of the house celebrate each occasion by playing music and dancing that alleviate the monotony of life and give a new vitality and increasingly emergent energy to the participants; in such gatherings, new things and manners by different people are practiced which could be called emergent manners. Since at first the musical instruments were expensive, they became valuable properties in Jose Arcadio's house; they played piano and accordion at first which were the emergent musical instruments and became dominant later on

In cultural materialism there is a close affinity between people and objects. Since human beings have different histories and biographies, their interpretations of an object are not unique and each object has a different potential role in 
various contexts. A new emergent perspective happens when insomnia pervades the village. The Indian said that "Once it gets into a house no one can escape the plague" (Marquez, p. 28). Like the air we breathe in, when an emergent perspective becomes dominant, everybody is affected by it. Another interesting textual evidence for such an assertion is when Marquez awakens us that "the illness was transmitted by mouth" (Marquez, p. 29).

Mouth could be considered as one of the sites in social transformation. It is a part of the body that interacts with space and objects. Each idea is expressed in a different manner through different mouths; that is due to the fact that no object has a single interpretation and they are polysemous and capable of transforming meaning within different contexts. It is offered that "objects also carry personal and emotional meanings; they can facilitate interpersonal interactions and assist a person to act upon him or herself (Woodward, 2007, p. 4). Therefore, mouth acts like a channel through which an idea is expressed. The emergence of a new perspective does not occur rapidly; it is carried out gradually. For instance, if it were that quick, they would not have time to create tags; that is why, Jose Arcadio Beuendia had enough time to mark the items with their names "With an inked brush he marked everything with its name: table, chair, clock, door, wall, bed, pan" (Marquez, p. 29).

The Macondo village was run by its own citizens, without any person as its only governor. However, the coming of Don Apolinar Moscote as a dissident (we call him dissident in that not only its people did not need the existence of such a person, but also they hate the village to get a political structure under somebody's surveillance), deconstructed the already established structures. Jose Arcadio Beuendia says that "In this town we do not give orders with pieces of paper;" he continues that "and so that you know it once and for all, we don't need any judge here because there's nothing that needs judging" (Marquez, p. 33). For Apolinar Moscote, it could be called a resistance against politically emergent perspectives. All through the novel we observe that some of the characters pretend not to remember some of their own particular behaviors, but after a while they start to repeat it over and over. For instance, Jose Arcadio Beuendia left the laboratory for several times and he went back to work in it again. Another instance is when Rebecca was brought to this house, as a child, she used to suck his finger and eat the chalk of the wall, although she abandoned it for a while, she resumed it when she reached adulthood "she went back to eating earth" (Marquez, p. 36). It demonstrates that the behaviors we carry out are mostly the repetition of our previous actions. When Arcadio ruled over Macondo, he ordered something, and after a while Úrsula reestablished them. Consequently, our life is a constant revival of those things that once were new or emergent and after a while became residual, now those residuals are awakened again.

If insomnia had lasted longer than what it really did, then it would have marked the end of a historical era and consequently the history of such people would have been entirely forgotten. Therefore, life is in a permanent transition between residual, dominant and emergent perspectives. Since we can cross the borders through sleeping in which the past and the future could be simultaneously observed, this is a great characteristic of mind, but when insomnia occurs people cannot get knowledge of a time other than the present one. In fact, their anxiety is caused by their inability to create mental bridges. They try to calm their fear by indulging themselves with dreams. Boundaries between the three perspectives are not that clear and adults are no more like the infants who according to Winnicott have the capacity to recognize the object as "not-me" the infants can recognize the boundaries through handling, sucking, and throwing the objects. The adults are entangled in a context which is saturated with indeterminacy

The dominant creates a balance between the residual, and the emergent. The dominant is greater than the residual because it is itself plus residual; that is to say, in dominant we have both the residual and the dominant; the word balance here reminds us of I.A Richards's theory about the role of literature; he believes that literature acts like a magnet that creates a balance and an equilibrium between the two wishes, "appetencies and aversions" (Williams, 1958, p. 263). This analogy paves the way for finding connections between the dominant and the magnet; the role of both could be regarded as the remover of tensions. We can call the dominant as an equilibrium and balancing state which is very close to Gramsci's definition of hegemony. Milner (2002) refers to Gramsci's definition of hegemony as:

The process by which a system of values and beliefs supportive of the existing ruling class becomes permeated throughout the whole of society. Hegemony is thus a value consensus, and one very often embodied in common sense, but constructed, nonetheless, in the interests of the ruling class. (p. 88)

Since the ruling class is the dominant class, we can conclude that hegemony is equal to the dominant class and in terms of what Williams (1977) argues:

Hegemony goes beyond 'culture', as its insistence on relating the 'whole social process' to specific distributions of power and influence. To say that 'men' define and shape their whole lives is true only in abstraction. In any actual society there are specific inequalities in means and capacity to realize this process. In a class society these are primarily inequalities between classes. (pp. 108-109) 
When a culture changes completely, it means that the dominant has been replaced with a new perspective. Here, it is reminiscent of Karrer (As cited in Vega González, 2000) that "collective amnesia results from hegemony of one culture over another" (p. 75). Henceforth, in One Hundred Years of Solitude we can replace the word 'culture" with the word "dominant" in the above definition. One of the main influential roles in such a change is played by the gypsies because the transaction of the goods by the gypsies is in fact a transaction of culture through which the alternation between the perspectives happens. Emergent perspectives are not very prevalent at first. Ideologically speaking, they allocate more space to themselves after being expanded. "He rose to be Commander in Chief of the revolutionary forces, with jurisdiction and command from one border to the other, and the man most feared by the government" (Marquez, p. 56).

The boundaries between dominant, residual and emergent are not clearly cut, the best sentence in the novel that elaborates on this assertion is "The houses, painted blue, then painted red, had ended up with an indefinable coloration" (Marquez, p. 65). The time that the Conservatives were dominant, their emblem was the blue color, but with their successive substitution of their colors by each other on the wall of the houses it is neither a transparent blue nor a red color. It is vague just like their own influence that was not easily discerned by the people under their ruling power. Most of the time those who are the holders of power and govern peoples' ideologies do not believe the speed with which the changes they wanted to create have actualized, like the time that Colonel Auerliano talks to his mother "What did you expect?" Úrsula sighed. "Time passes;" "That's how it goes;" Aureliano admits; "but not so much"' (Marquez, p. 65).

Once everybody in the Beuendia family was to some extent concerned with Rebecca, and she was appreciated by men, so this being in the center of attention does not let one be forgotten; however, little by little she becomes like a residual perspective, such a fact is declared by Marquez in the novel:

\begin{abstract}
As soon as they took the body out, Rebecca closed the doors of her house and buried herself alive, covered with a thick crust of disdain that no earthly temptation was ever able to break. She went out into the street on one occasion, when she was very old, with shoes the color of old silver and a hat made of tiny flowers, during the time that the Wandering Jew passed through town and brought on a heat wave that was so intense that birds broke through window screens to come to die in the bedrooms. The last time anyone saw her alive was when with one shot she killed a thief who was trying to force the door of her house. Except for Argénida, her servant and confidante, no one ever had any more contact with her after that. At one time it was discovered that she was writing letters to the Bishop, whom she claimed as a first cousin. But it was never said whether she received any reply. The town forgot about her. (Marquez, p. 69)
\end{abstract}

Not only the ideas and concepts, but also the human beings become residual and marginalized. We constantly observe the institutionalization of new emergent perspectives which could be replaced by new series of novel issues. Sometimes, we are fighting to make something dominant, while they are not meaningful for those for whom we are prescribing them. We try to implement our power, as presented in the novel in the dialogue between Colonel Grenledo Marquez and Colonel Auerliano Beuendia. "You're lucky because you know why;" he answered, "As far as I'm concerned, I've come to realize only just now that I'm fighting because of pride."

"That's bad;" Colonel Gerineldo Márquez said. Colonel Aureliano Buendía was amused at his alarm. "Naturally;" he said. "But in any case, it's better than not knowing why you're fighting." He looked him in the eyes and added with a smile: "Or fighting, like you, for something that doesn't have any meaning for anyone" (Marquez, p. 70). The following process could be offered to indicate the way significant points become dominant in the novel.

\title{
The gypsies $\rightarrow$ sitting in laboratory $\rightarrow$ love affairs (polygamy) $\rightarrow$ war $\rightarrow$ war + love affair $\rightarrow$ monogamy
}

There are three main factors influential in the men changing from polygamy to monogamy. First, the rigidity of mothers in bringing up their sons and imposing their own way of thought regarding feminist female feelings and emotions, that is why the more we move forward in the novel, the more women develop their power to exert authority; second, the boys' hardworking to decode and decipher Melquíades' manuscripts. The boys remain for long hours in Melquíades' room and very scarcely come out of the room to either go to the toilet or the kitchen. In this respect, they do not devote their time to other people and specifically to other women.

Monogamy is an emerging aspect in One Hundred Years of Solitude and little by little it turns out to be dominant; there is always interplay between these perspectives. The dominant norm which is polygamy becomes residual. Religion, particularly Catholicism, is a noteworthy issue in the novel. Amaranta attempts to escape from the unlawful tendencies that Auerliano Jose has towards her; it is here for the first time we hear about the role of pope and Catholicism in religion. "That was how he suffered in exile, looking for a way of killing her with, his own death, until he heard some old man tell the tale of the man who had married his aunt, who was also his cousin, and whose son ended up being his own grandfather;" in addition,

Can a person marry his own aunt?" he asked, startled. "He not only can do that, a soldier answered him. "But we're 
fighting this war against the priests so that a person can marry his own mother. Two weeks later he deserted. He found Amaranta more withered than in his memory, more melancholy and shy, and now really turning the last corner of maturity, but more feverish than ever in the darkness of her bedroom and more challenging than ever in the aggressiveness of her resistance. "You're a brute," Amaranta would tell him as she was harried by his hounds. "You can't do that to a poor aunt unless you have a special dispensation from the Pope. (Marquez, p. 77)

The fear of permanent polygamy was due to Colonel Aurliano Beuendia and his seventeen sons, once he himself referred to this fact that they are exactly like him

Everywhere he met adolescents who looked at him with his own eyes, who spoke to him with his own voice, who greeted him with the same mistrust with which he greeted them, and who said they were his sons. He felt scattered about, multiplied, and more solitary than ever. (Marquez, p. 85)

Gift and gift giving is a highly significant element in cultural materialism; e.g., Fernanda's father used to send gifts for his grandchildren on Christmas day. The gift exchanging produces social relations and links the people. The act of gift giving places Fernanda in connection with her own origin, family ideology and etiquettes; that is why, he cannot accept the norms and the dominant rules to which she is brought. This house in Macondo is a place for homeless residents that houses people without permanent private dwelling e.g. all school friends of Meme, Colonel Auerliano Beuendia's 17 sons and so many other new comers. Each with his/her own personality collected in a unique place using the same services provided by the house owners. Úrsula calls for a change in particularly Catholicism which helps to decrease in polygamy; we observe that Jose Arcadio Segundo's interest in church is obvious from the following quotation: "No one knew then exactly when he began to ring the bells in the church tower and assist Father Antonio Isabel, the successor to "The Pup," at mass, and take can of the fighting cocks in the courtyard of the parish house. When Colonel Gerineldo Márquez found out, he scolded him strongly for learning occupations repudiated by the Liberals. "The fact is," he answered, "I think I've turned out to be a Conservative." He believed as if it had been determined by fate. Colonel Gerineldo Márquez, scandalized and told Úrsula about it. "It's better that way," she approved. "Let's hope that he becomes a priest so that God will finally come into this house" (Marquez, pp. 94-95).

We observe a type of unknown polyandry when "At the end of two weeks Aureliano Segundo realized that the woman had been going to bed alternately with him and his brother;" then Jose Arcadio Beuendia didn't see the woman again (Marquez, p. 96). Jose Arcadio Segundo is moving to become monogamous and it is directly said that, "Except for his precarious adventure with Petra Cotes, he had never known a woman. Úrsula had considered him as the quietest example the family had ever produced in all its history (Marquez, p. 98). Colonel Auerliano Beuendia who was polygynous at first now has affair with nobody "Enclosed in his workshop, his only relationship with the rest of the world was his business in little gold fishes" (Marquez, p. 100). "He exchanged little fish for gold coins and then converted the coins into little fish, and so on, with the result that he had to work all the harder with the more he sold in order to satisfy an exasperating vicious circle" (Marquez, p.101, my italics). The term "vicious circle" shows the uselessness of these changes. Fernanda de Caprio is the best epitome of religiosity in this family; it is her complete sacredness that makes her attempt to abolish polygyny; that is why,

Fernanda carried a delicate calendar with small golden keys on which her spiritual adviser had marked in purple ink the dates of venereal abstinence. Not counting Holy week, Sundays, holy days of obligation, first Fridays, retreats, sacrifices, and cyclical impediments, her effective year was reduced to forty-two days that were spread out through a web of purple crosses. (Marquez, p. 105)

When Fernanda holds the power, she instills her religiosity into the house. For instance, she removes the dominant aloe branch and loaf of bread and substitutes it with an emerging element again concerned with her religion and that is her hanging of a portrait of the sacred heart of Jesus Christ. The power of Catholics is strengthened, in the discussion between the six lawyers and Colonel Auerliano Beuendia,

They asked first that he renounce the revision of property titles in order to get back the support of the Liberal landowners. They asked, secondly, that he renounce the fight against clerical influence in order to obtain the support of the Catholic masses. They asked, finally, that he renounce the aim of equal rights for natural and illegitimate children in order to preserve the integrity of the home. (Marquez, p. 86)

These transitions between the three perspectives are all done by those who want to seize the power and to make themselves and their attitudes dominant; that is why, Colonel Auerliano Beuendia demonstrates that "all we're fighting for 
is power" (Marquez, p. 86). Subsequently, war and the news about it become the dominant concerning points in the novel.

At first people showed resistance toward the residence of de Caprio in that he was viewed as a foreigner; however, after a while the emergent members increased highly that made the distinction between the original members and new comers impossible. "The Street of the Turks, enriched by well-lit stores with products from abroad, displacing the old bazaars with their bright colors;" (Marquez, p. 114) and "The old policemen were replaced by hired assassins with machetes" (Marquez, p. 118).

Úrsula was so confused that she mixed up past and present. Fear of death is in fact a fear of being forgotten and then to become residual; that is why, Colonel Auerliano undergoes a vicious circle to make the fish and Amaranta sews her winding cloth just to open it again. "It was then that she understood the vicious circle of Colonel Aureliano Buendía's little gold fishes. The world was reduced to the surface of her skin and her inner self was safe from all bitterness" (Marquez, p. 137). The second Auerliano used to bring out the battery of the clock just to put it in again "Watching him putting in latches and repairing clocks, Fernanda wondered whether or not he too might be falling into the vice of building so that he could take apart like Colonel Auerliano Buendía and his little gold fishes, Amaranta and her shroud and her buttons, José Arcadio and the parchments, and Úrsula and her memories" (Marquez, p. 154). At first even death was a new and emergent event but later on it pervaded the whole village:

\begin{abstract}
At first they thought it was a plague. Housewives were exhausted from sweeping away so many dead birds, especially at siesta time, and the men dumped them into the river by the cartload. On Easter Sunday the hundred-year-old Father Antonio Isabel stated from the pulpit that the death of the birds was due to the evil influence of the Wandering Jew, whom he himself had seen the night before. He described him as a cross between a billy goat and a female heretic, an infernal beast whose breath scorched the air and whose look brought on the birth of monsters in newlywed women. (Marquez, p. 167)
\end{abstract}

The residuals may appear for more times in the future "With neither the time nor the resources to halt the challenge of nature, Santa Sofía de la Piedad spent the day in the bedrooms driving out the lizards who would return at night" (Marquez, p. 174). The dominant perspectives fade away after a while and the novel presents it to us through the image cobweb that offers a surface to prevent objects from being observed clearly. The dominant is "the incorporation of the actively residual- by reinterpretation, dilution and projection" (Williams, 1977, p. 123). In the way enumerated, the residual can incorporate itself into the dominant. In this sense, the dominant resembles a fading coal which needs an inspiring force and source to lighten it again;" and "The cobwebs fell like snow on the rose bushes, carpeted the beams, cushioned the walls" (Marquez, p. 175). All in all, the effect of culture as "a whole way of life, material, intellectual and spiritual" is observed in the novel (Williams, 1958, p. xiv). Since the dominant culture is concerned with "personal and social relationship," the offspring of individuals' involvement leads to the construction of the dominant or hegemony.

\title{
3. Conclusion
}

This paper sought to explore the significance of individual's agency in contributing to the social changes. Such significance was represented through various concepts like culture, ideology, transformation, unsuccessful emerges, original balance and equilibrium, customer/service, colors, books/parchments, music, borders, and gift and gift giving. The change in relationship between men and women is a matter of interest in this novel. There are three main factors influential in the men change from polygamy to monogamy. First, the rigidity of mothers in bearing their sons and imposing their own way of thought regarding female feelings and emotions. Second, the boys' hardworking to decode and decipher Melquíades' manuscripts for which they remain for long hours in Melquíades' room and rarely come out of the room to either go to the toilet or the kitchen. Third, it is the significance of religion particularly Catholicism. Johnson (1998) explores that "Religion is a critical part of the development of every known society in history" (p. 1). Consequently, the familial structural changes are due to the dominant religiosity.

Monogamy as an epitome of other social changes is an emerging aspect in One Hundred Years of Solitude and gradually it turns out to become dominant. There is always interplay between these perspectives. That is why the present authors concentrated deeply on the way individuals influenced polygamy to become residual and to be replaced with monogamy. Therefore, in later generations the number of women corresponded to each man is reduced and men agree to have only one woman and at the end Gaston. He has only one wife all through his life so he stands for the monogamous men .Consequently, love is presented here with Gaston, whereas polygynous men are less concerned with the issue of love. In terms of the already accomplished explorations it could be argued that the behavior and values of citizens leads to the cultural or social changes. The more emergent perspectives we experience, the more unpredictable 
our culture becomes. The emergent challenges the dominant and the interplay between them helps the procession of the society in a natural way.

\section{References}

Aizenberg, E. (1992). Historical Subversion and Violence of Representation in García Márquez and Ouologuem. PMLA: Publications of the Modern Language Association of America, vol. 107, no. 5, pp. 1235-1252.

Amoore, L. (Ed.). (2005). The Global Resistance Reader. London: Routledge.

Booker, M. K. (1993). The Dangers of Gullible Reading: Narrative as Seduction in García Márquez's Love in the Time of Cholera, Studies in 20th Century Literature, vol. 17, no. 2. pp. 181-195.

Browitt, J. (2007). Tropics of Tragedy: the Caribbean in Gabriel García Márquez's One Hundred Years of Solitude. Shibboleths: A Journal of Comparative Theory, vol. 2, no. 1, pp.16-33.

Erickson, D. (2009). Ghosts, Metaphor, and History in Toni Morrison's Beloved and Gabriel García Márquez's One Hundred Years of Solitude. New York: Palgrave Macmillan.

González, S. V. (2000). Mundos Mágicos: La Otra Realidad en La Narrativa de Autoras Afroamericanas. Universidad de Oviedo.

Harré, R. (2002). Material Objects in Social Worlds. Theory, Culture \& Society, vol. 19, no. 5-6, pp. 23-33.

Johnson, Ch. W.( 1998). Religion in One Hundred Years of Solitude and The Lost Steps. Retrieved on, November 20, 2015. From: <<http:// www. charleswjohnson.name/essays/eng11religion.pdf〉>

Martin, G. (2012). The Cambridge Introduction to Gabriel García Márquez. Cambridge: Cambridge University Press.

Miller, J. C. (2014). Onomatology of Male Characters in One Hundred Years of Solitude of Gabriel García Márquez. Literary Onomastics Studies, vol. 1, no.1, pp. 66-74.

Milner, A. (2002). Re-Imagining Cultural Studies: The Promise of Cultural Materialism. London: Sage.

Moraña, M. (1990). Modernity and Marginality in Love in the Time of Cholera. Studies in 20th Century Literature, vol. 14, no.1, pp. 27-43.

Ochoa, A. M. (2005). García Márquez, Macondismo, and the Soundscapes of Vallenato. Popular Music, vol. 24, no. 2, pp. $207-222$.

Ortega, J., (2014). Gabriel García Márquez and the Powers of Fiction. Austin: University of Texas Press.

Roberts, B. W. , \& Vander Linden, M. (2011). Investigating Archaeological Cultures: Material Culture, Variability, and Transmission. Springer New York. pp. 1-21.

Ruckel, T. S. (2006). The Scent of a New World Novel: Translating the Olfactory Language of Faulkner and Garcia Márquez, Doctoral dissertation, University of Southern Mississippi.

Simmel, G.. (1957). Fashion. American Journal of Sociology, vol. 62, no. 6, pp. 541-558. Retrieved from<<http://www.jstor.org/stable/2773129>>

Sims, R. L. (1994). Dominant, Residual, and Emergent: Recent Criticism on Colombian Literature and Gabriel Garcia Márquez. Latin American Research Review, vol. 29, no. 2, pp. 223-235.

Sklair, L (1998). Transnational Practices and the Analysis of the Global System. London School of Economics and Political Science, pp.1-14. From: <<http://www.transcomm.ox.ac.uk/working\%20papers/sklair.pdf〉>

Sheumaker, H., \& Wajda, S. T. (Eds.). (2008). Material Culture in America: Understanding Everyday Life. ABC-CLIO.

Vega-González, S. (2001). Memory and the Quest for Family History in One Hundred Years of Solitude and Song of Solomon. Comparative Literature and Culture. vol. 3, no.1, pp. 1-9.

Williams, R. (1958). Culture and Society, 1780-1950. London and New York: Colombia University Press.

--.. (1977). Marxism and Literature. London and New York: Oxford University Press.

---. (1983). Towards 2000. London: Chatto \& Windus.

---. (1961). The Long Revolution. London and New York: Columbia University Press.

Woodward, I. (2007). Understanding Material Culture. Los Angeles: Sage Publications. 